\title{
progreso en el empleo del calor de los gases de escape de los hornos rotatorios de via seca
}

\section{fortschritte in der ausnutzung der abwärme von trockendrehöfen}

\section{G. RUPPERT}

(«Zement-Kalk-Gips», 13, núm. 8, agosto 1960, pág. 366.)

Se discuten algunos resultados industriales obtenidos en hornos rotatorios de vía seca para la fabricación de cemento.

En el caso de hornos rotatorios equipados con calcinadores pueden recuperarse $40 \mathrm{kcal} / \mathrm{kg}$ de clínker de los gases de escape.

Para un horno Lepol, con un consumo calorífico de $170 \mathrm{kcal} / \mathrm{kg}$ de clínker, se ha conseguido un ahorro de $50 \mathrm{kcal} / \mathrm{kg}$ de clínker al tomar aire del centro del enfriador.

En el caso de un nuevo horno Lepol de 900 toneladas de clínker por día, con un consumo calorífico de sólo $760 \mathrm{kcal} / \mathrm{kg}$ de clínker, el calor procedente del enfriador se empleaba (unas 50-60 kcal/kg de clínker) en una instalación de secado y molienda conjunta.

En el caso de un viejo horno rotatorio, convertido en un horno equipado con precalentador en suspensión gaseosa (Humboldt), con un consumo calorífico de $830 \mathrm{kcal} / \mathrm{kg}$ de clínker, pueden beneficiarse $135 \mathrm{kcal} / \mathrm{kg}$ de clínker del calor de los gases de escape; además, seca el crudo para un horno Lepol.

Una instalación de parrilla móvil, con un consumo calorífico de $1.060 \mathrm{kcal} / \mathrm{kg}$ de clínker, beneficia alrededor de $80 \mathrm{kcal} / \mathrm{kg}$ de clínker para el secado de las materias primas empleando el aire procedente del enfriador. 